\title{
Effect of academic stress on physical activity level and cognitive functions in first year medical students: An observational study
}

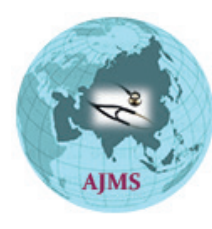

\author{
Jitender Sorout ${ }^{1}$, Satyanath Reddy Kodidala ${ }^{2}$, Harsha Soni ${ }^{3}$, Priyanka Singh ${ }^{4}$, \\ Nirmal Sharma ${ }^{5}$ \\ ${ }^{1}$ Tutor, ${ }^{2}$ Assistant Professor, Department of Physiology, K.D. Medical College Hospital and Research Centre, Mathura, \\ Uttar Pradesh, India, ${ }^{3}$ Post Graduate, Department of Physiology, RUHS College of Medical Sciences, Jaipur, \\ Rajasthan, India, ${ }^{4}$ Assistant Professor, Department of Physiology, G S Medical College, Pilkhuwa, Hapur. Uttar \\ Pradesh, India, ${ }^{5}$ Occupational Therapist, Jaipuria Hospital. Jaipur, India
}

Background: Newly admitted medical students experience a different curriculum, which can be a stressor and may be the reason of stress during student life. Stress may affect physiological, psychological and cognitive functions of the students. Aims and Objective: Aim of the study was to assess the effect of academic stress on physical activity level and cognitive functions in first year medical students. Materials and Methods: This observational study was conducted on 30 healthy newly admitted medical students (18 -25 years). The data was collected thrice, baseline, after two months and after four months. Stress was assessed by using DASS and Cohen perceived stress scale (PSS). GPAO was used to estimate the physical activity level. And cognitive functions were assessed by using subjective method (MMSE questionnaire) and objective method (P300). Results: No significant difference of mean values of age, height, weight, BMI, physical activity level, DASS score, PSS and P300 latency were observed over the time to which recording was taken. The mean score of PAL represents the high physical activity. But the score of DASS and PSS represent severe and moderate stress level respectively. The significant difference was seen in the mean values of MMSE score and P300 amplitude over the time to which recording taken. Conclusion: On the basis of the current study results, we conclude that students have stress during their academic period. This stress might be helpful in potentiating the cognitive functions with the optimum physical activity.

Key words: Academic stress; Physical activity level; Cognition; DASS; Medical students.

\section{Access this article online}

Website:

http://nepjol.info/index.php/AJMS

DOI: 10.3126/ajms.v11i5.29323

E-ISSN: 2091-0576

P-ISSN: 2467-9100

Copyright (c) 2020 Asian Journal of Medical Sciences

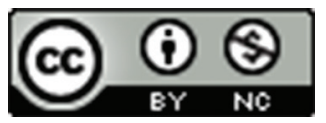

This work is licensed under a Creative Commons Attribution-NonCommercial 4.0 International License.

\section{INTRODUCTION}

The newly admitted medical students experience a new environment after getting admission in medical college. To form the well experienced health care professionals (doctors) a medical college has very tight academic schedule. Some of them are: extensive curricula, numerous academic requirements and various types ofexaminations. ${ }^{1,2}$ One of the most eminent stressors in students' lives is academic stress. ${ }^{3}$ The effectiveness of academic stress as a psychosocial stress is well established regarding repercussions on physiological and psychological health. ${ }^{4}$ Furthermore, in academic stress periods, different effects on psychological parameters can be detected, such as increased anxiety, poor sleep quality, a negative effect on well-being, increased negative affectivity and increases in the prevalence of depressive symptoms. ${ }^{5-10}$ From these findings, it can be assumed that times of high academic stress have a negative impact on health-related physiological and psychological outcomes. Short period of stress can potentiate memory formation. In contrast, more ever prolonged stress can have deleterious effect upon broad aspects of cognition. Some evidence suggest that some of these effect can probably be attributed to the reversible changes in the morphology of neurons 
within the hippocampus, a region of brain that is central to learning and memory. ${ }^{11}$ Cognitive functions are a brain activity which includes: memory, attention, visual-spatial, and executive functions, while complex cognitive processes include: thinking (abstract, cause and effect, creative thinking, and planning) and language functions. ${ }^{12}$ These cognitive functions are necessary for daily routine activities and must for such a creative fine profession. Physical activity improves health. ${ }^{13,14}$ Intervention studies suggested that increased physical activity results in profound reductions in physical ailments. ${ }^{15,16}$ There is a similar picture for exercise on mental health outcomes. Those who exercise suffer from less depression, anxiety, fatigue, and cognitive impairments. ${ }^{17-22}$

\section{MATERIAL AND METHODS}

The present observational study was conducted in the department of physiology of RUHS College of Medical Sciences, Jaipur. The data was collected from the 30 newly admitted $1^{\text {st }}$ year medical students (voluntary participation) after getting consent and institutional ethical clearance(RUHS-CMS/Ethics Comm./2018/112).

Procedure and instrument used: The data was collected thrice, baseline, after two months and after four months by using following instruments and questionnaire.

a. DASS and Cohen Perceived Stress Scale: For assessment of academic stress. ${ }^{23,24}$

b. GPAQ (global physical activity questionnaire):for assessment of physical activity level (PAL). ${ }^{25}$

c. MMSE (mini mental state examination): for assessment of cognitive functions. ${ }^{26}$

d. P300 (ERP): for assessment of cognitive functions, using NCV/EMG/EP Machine.

\section{RESULTS}

The mean values of data collected thrice were presented in the Table 1.
There was no significant difference of mean values of age, height, weight, BMI, physical activity level, DASS score, PSS and P300 latency over the time to which recording was taken. The mean score of PAL represents the high physical activity. But the score of DASS and PSS represent severe and moderate stress level respectively (Table 2).

The significant difference was seen in the mean values of MMSE score and P300 amplitude over the time to which recording taken (Table 1).

\section{DISCUSSION}

The present study was designed to observe the status of academic stress with physical activity level and cognitive functions. Stress can either potentiate or deteriorate the cognitive functions. ${ }^{11}$ Academic stress is the stress gained by a student during his/her academic life because of hectic schedule. Due to their busy academic schedule most of students unable to spare time for physical activities. Keinan et al. reported that degree of stress experienced by undergraduate students may differ from non student peers and from one school year to another and also argues that feeling of frustration, anxiety, and depression are common among the undergraduate students. ${ }^{27}$ Some students are often under stress because of interpersonal relationships, Lack of guidance, excessive academic work load and socialization pressure. ${ }^{28,29}$ Various studies explained that exercise or physical activity decreases the load of depression, anxiety, fatigue, and cognitive impairments among individuals. ${ }^{17-22}$ Pradhan G. et al. revealed that excessive stress affects cognitive functions and may negatively affect their performance in the examinations. The present study showed that DASS and PSS score of 1st year medical students had severe and moderate stress level respectively over a period, which was same as baseline. This means newly admitted medical students will be under stress due to new environment. But in the physical activity level (PAL) there was no significant change which remain same

\begin{tabular}{|c|c|c|c|c|c|}
\hline \multirow[t]{2}{*}{ Variables } & \multicolumn{3}{|c|}{ Mean $\pm S D$} & \multirow[t]{2}{*}{ (F value) } & \multirow[t]{2}{*}{$P$ value } \\
\hline & Baseline & After 2 months & After 4 months & & \\
\hline Age (Years) & $20.07 \pm 1.70$ & $20.16 \pm 1.68$ & $20.63 \pm 1.81$ & 0.91482 & .404409 \\
\hline Height $(\mathrm{cm})$ & $173.33 \pm 8.87$ & $173.26 \pm 8.82$ & $173.6 \pm 8.79$ & 0.01196 & .98811 \\
\hline Weight $(\mathrm{Kg})$ & $64.43 \pm 11.64$ & $65.9 \pm 10.98$ & $66.13 \pm 9.82$ & 0.21664 & .805652 \\
\hline BMI $\left(\mathrm{kg} / \mathrm{m}^{2}\right)$ & $21.89 \pm 4.56$ & $21.43 \pm 5.35$ & $21.97 \pm 6.14$ & 0.15347 & .857959 \\
\hline PAL (GPAQ) & $1531 \pm 899.32$ & $1626.33 \pm 663.77$ & $1629.2 \pm 577.72$ & 0.17756 & .837615 \\
\hline DASS Score & $28.8 \pm 16.75$ & $32.4 \pm 12.64$ & $32.1 \pm 12.31$ & 0.61306 & .544015 \\
\hline PSS Score & $15.2 \pm 4.1$ & $16.23 \pm 4.47$ & $17.26 \pm 5.08$ & 1.35679 & .262878 \\
\hline MMSE & $24.57 \pm 2.86$ & $24.96 \pm 2.09$ & $26.6 \pm 1.45$ & 7.11711 & $.001^{*}$ \\
\hline P300 latency (ms) & $272.20 \pm 43.46$ & $267.98 \pm 33.99$ & $262.72 \pm 27.94$ & 0.53123 & .589774 \\
\hline P300 Amplitude $(\mu \mathrm{V})$ & $2.61 \pm 1.87$ & $4.45 \pm 1.42$ & $4.73 \pm 1.08$ & 17.67 & $<.00001^{*}$ \\
\hline
\end{tabular}




\begin{tabular}{llll}
\multicolumn{2}{l}{ Table 2: Status of PAL and Stress over a time } \\
period
\end{tabular}

as baseline (highly active).Even in stressful environment the present study participants (medical students) were physically active.

Betterment in cognitive functions was also observed over the time period. From MMSE score the significant betterment of cognitive functions was observed. The mean P300 latency (ms) was decreased as over the time period but not significantly. But in the P300 amplitude $(\mu \mathrm{V})$ there was significant rise indicating betterment in cognition. Long time Stress can affect cognition through sympathetic nervous system and brain -pituitary-adrenocortical axis. Himani et al..$^{30}$ reported that the latency of P300 was found to be significantly delayed in cases of major depression as compared to that of control group but amplitude was depressed. Some stressors may be appraised as positive and may be deleterious to cognition..$^{31,32}$ But the present study participants (medical students) have best cognitive functions and good physical activity level even in stressed conditions.

\section{CONCLUSION}

From the present study results we can conclude that students have stress during their academic period. And this stress might be helpful in potentiating the cognitive functions with the optimum physical activity.

\section{Limitations}

In the present study the study group was small and subjects participated were physically highly active. So the further research studies must be on different physical activity level and on large students group.

\section{ACKNOWLEDGEMENT}

We would like to thank all the study participants. We also extend our thankful regards to technical staff of department of physiology, RUHS College of Medical Sciences, Jaipur.

\section{REFERENCES}

1. Sreerama Reddy CT, Shankar PR, Binu VS, Mukhopadhyay C Ray B and Menezes RG. Psychological morbidity, sources of stress and coping strategies among undergraduate medical students of Nepal. BMC Med Educ.2007; 7:26.

https://doi.org/10.1186/1472-6920-7-26

2. Robert LC, Lawerence WS and George K J. Perceived level of stress among university undergraduate students in Edmenton, Canada. Perceptual and motor skills. 1992; 75:552-554. https://doi.org/10.2466/pms.1992.75.2.552

3. Kohn JP and, Frazer GH. An academic stress scale: identification and rated importance of academic stressors. Psychol Rep.1986; 59:415-426.

https://doi.org/10.2466/pr0.1986.59.2.415

4. Malarkey WB, Pearl DK, Demers LM, Kiecolt-Glaser JK and Glaser R. Influence of academic stress and season on 24-hour mean concentrations of $\mathrm{ACTH}$, Cortisol, and $B$ - endorphin. Psychoneuro endocrinology.1995; 29:499-508.

https://doi.org/10.1016/0306-4530(94)00077-N

5. Putwain D. Researching academic stress and anxiety in students: some methodological considerations. Br Educ Res J.2007; 33:207-219.

https://doi.org/10.1080/01411920701208258

6. Lund HG, Reider BD, Whiting $A B$ and Prichard JR. Sleep patterns and predictors of disturbed sleep in a large population of college students. J Adolescent Health.2010; 46(2):124-132. https://doi.org/10.1016/j.jadohealth.2009.06.016

7. Edwards JR and Rothbard NP. Work and family stress and wellbeing: an examination of person- environment fit in the work and family domains. Organ Behav Hum Decis Process. 1999; 77(2):85-129.

https://doi.org/10.1006/obhd.1998.2813

8. Watson D and Pennebaker JW. Health complaints, stress, and distress: exploring the central role of negative affectivity. Psychol Rev.1989; 96(2):234-254.

https://doi.org/10.1037/0033-295X.96.2.234

9. Dyrbye LN, Thomas MR and Shanafelt MD. Systematic review of depression, anxiety, and other indicators of psychological distress among U.S. and Canadian medical students. Acad Med.2006; 81(4):354-373.

https://doi.org/10.1097/00001888-200604000-00009

10. Sharif $W$, Khalid $U$ and Ali A. Association of academic stress with sleeping difficulties in medical students of Pakistani Medical school: a cross sectional survey. Peer J. 2015; 3:e840.

https://doi.org/10.7717/peerj.840

11. Kerr DS, Campbell LW, Thibault $O$ and Landfield PW. Hippocampal glucocorticoids receptor activation enhance voltage gated $\mathrm{Ca}++$ conductances: relevance to brain aging. Proc Natl Acad Sci USA.1992;89:8527-8531.

https://doi.org/10.1073/pnas.89.18.8527

12. Evans JJ. Basic concepts and principles of neuropsychological assessment. In: HalliganP.W., KischkaU., Marshall J.C., editors. Handbook of Clinical Neuropsychology. University Press; Oxford, UK: 2003.pp.15-26.

https://doi.org/10.1093/acprof:oso/9780199234110.003.02

13. Wei M, Gibbons LW, Kampert JB, Nichaman MZ and Blair SN. Low cardio respiratory fitness and physical in activity as predictors of mortality in men with type 2 diabetes. Ann Intern Med. 2000; 132(8):605-611.

https://doi.org/10.7326/0003-4819-132-8-200004180-00002

14. Blair SN, Kampert JB, Kohl HW, Barlow CE, Macera CA, Paffenbarger RS Jr, et al. Influences of cardio respiratory fitness and other precursors on cardiovascular disease and all-cause mortality in men and women. JAMA.1996; 276(3):205-210. https://doi.org/10.1001/jama.1996.03540030039029 
15. Ross R, Dagnone D, Jones PJH, Smith H, Paddags A, Hudson $R$, et al. Reduction in obesity and related comorbid conditions after diet-induced weight loss or exercise-induced weight loss in men-a randomized, controlled trial. Ann Intern Med. 2000; 133(2):92-103.

https://doi.org/10.7326/0003-4819-133-2-200007180-00008

16. Whelton SP, Chin A, Xin X and He J. Effect of aerobic exercise on blood pressure: A meta-analysis of randomized, controlled trials. Ann Intern Med.2002; 136(7):493-503. https://doi.org/10.7326/0003-4819-136-7-200204020-00006

17. Rethorst CD, Wipfli BM and Landers DM. The antidepressive effects of exercise: A meta-analysis of randomized trials. Sports Med.2009; 39(6):491-511.

https://doi.org/10.2165/00007256-200939060-00004

18. Wipfli BM, Rethorst CD and Landers DM. The anxiolytic effects of exercise: ameta-analysisof randomized trials and doseresponse analysis. J Sport Exerc Psychol.2008; 30(4):392-410. https://doi.org/10.1123/jsep.30.4.392

19. Resnick HE, Carter EA, Aloia M and Philips B. Cross-sectional relationship of reported fatigue to obesity, diet, and physical activity: Results from the Third National Health and Nutrition Examination Survey. J Clin Sleep Med. 2006; 2(2):163-169. https://doi.org/10.5664/jcsm.26511

20. Theorell-Haglow J, Lindberg $\mathrm{E}$ and Janson $\mathrm{C}$. What are the important risk factors for daytime sleepiness and fatigue in women? Sleep.2006; 29(6):751-757.

https://doi.org/10.1093/sleep/29.6.751

21. Lautenschlager NT, Cox KL, Flicker L, Foster JK, van Bockxmeer $\mathrm{FM}, \mathrm{Xiao} \mathrm{J}$, et al. Effect of physical activity on cognitive function in older adults at risk for Alzheimer disease- A randomized trial. JAMA. 2008; 300(9):1027-1037. https://doi.org/10.1001/jama.300.9.1027

22. Rovio S, Kareholt I, Helkala EL, Viitanen M, Winblad B, Tuomilehto J, et al. Leisure-time physical activity at midlife and the risk of dementia and Alzheimer's disease. Lancet Neurol. 2005; 4(11):705-711.

https://doi.org/10.1016/S1474-4422(05)70198-8
23. Lovibond, S.H.; Lovibond, P.F. (1995). "Manual for the Depression Anxiety Stress Scales" 2nded.). Sydney: Psychology Foundation.(Available from The Psychology Foundation, Room 1005 Mathews Building, University of New South Wales, NSW 2052, Australia). https://doi.org/10.1037/t01004-000

24. Cohen S, Kamarck T and Mermelstein R. A global measure of perceived stress. Journal of Health and Social Behavior. 1983; 24 (4):385-396. https://doi.org/10.2307/2136404

25. Armstrong $T$ and Bull FC. Development of World Health Organization Global Physical Activity Questionnaire (GPAQ). J Public Health.2006; 14(2); 66-70. https://doi.org/10.1007/s10389-006-0024-x

26. Folstein MF, Folstein SE and McHugh PR. Mini Mental State. A practical method for grading the cognitive state of patients for clinician. J Psychiatr Res. 1975 ; 12(3);189- 198. https://doi.org/10.1007/BF00138093

27. Keinan G, Perlberg A. sources of stress in academe: the Israeli case. Higher Eduv' cation. 1986; 15(1/2):73-88. https://doi.org/10.1046/j.1365-2923.2003.01405.x

28. Shirom, A. Students's stress. Higher Education. 1986; 15 (6): 667-676. https://www.jstor.org/stable/3447049

29. Radcliff $\mathrm{C}$ and Lester $\mathrm{H}$. undergraduate Medical Education. Perceived stress during undergraduate medical training: A qualitative study. Medical Education 37(1),32-38.

30. Himani A, Tandon OP and Bhatia MS. A study of P300event related evoked potential in the patients of major depression. Indian J Physiol Pharmacol. 1999; 43:367-372. https://doi.org/10.1152/physrev.00041.2006

31. McEwen BS. Physiology and neurobiology of stress and adaptation: central role of the brain. Physiol Rev. 2007; 87(3):873-904.

32. Smith CA and Kirby LD. The role of appraisal and emotion in coping and adaptation. In: Contrada RJ, Baum A, editors. The handbook of stress science. Springer Publishing Company; New York: 2011. pp. 195-208.

\footnotetext{
Authors Contribution:

JS - Concept and design of the study, data collection and statistical analysis; SNR - Interpretation of results, drafting of the manuscript and revision of manuscript ; HS - Data collection, statistics and first drafting of manuscript; PS - Discussion, statistical analysis, coordination, moral support for the study; NS - Data collection and drafting of manuscript with critical corrections

Work attributed to:

Department of Physiology, RUHS College of Medical Sciences, Jaipur, Rajasthan, India.

Orcid ID:

JitenderSorout - (1) https://orcid.org/0000-0002-1510-0982

Satyanath Reddy - it https://orcid.org/0000-0001-7830-7211

Harsha Soni - (i) https://orcid.org/0000-0002-1638-7209

Priyanka Singh - (iD https://orcid.org/0000-0003-4710-7019

Nirmal Sharma - (10 https://orcid.org/0000-0002-5362-8200

Source of support: None, Conflicts of Interest: None
} 